\title{
Pengujian Performa Payload Video UAV untuk Persiapan Implementasi pemantauan Kapal Illegal Fishing
}

\author{
Sunar*1, Ari Sugeng Budiyanta ${ }^{2}$ \\ ${ }^{1,2}$ Pusat Teknologi Penerbangan, LAPAN, Bogor, Indonesia \\ e-mail: *11 sunar@lapan.com, ${ }^{2}$ ari.sugeng@lapan.go.id
}

\begin{abstract}
Abstrak
Pusat Teknologi Penerbangan LAPAN mengembangkan sistem maritime surveillance system (MSS) berbasis aplikasi unmanned aerial vehicle (UAV), khususnya untuk mendukung penanganan kapal illegal fishing. Dalam tulisan ini dibahas pengujian payload video. Pengujian dilakukan di Pamengpeuk, garut, di area pinggir pantai pada tanggal 31 Agustus 2019. Tempat ini dipilih untuk mensimulasikan kondisi dengan kecepatan angin yang mirip sama dengan kondisi operasi di lingkungan laut saat implementasi riil operasi. Payload yang digunakan memiliki fitur video recording dengan kemampuan untuk melakukan zoom-in, zoomout dan locking target posisi. UAV terbang loiter dengan ketinggian $300 \mathrm{~m}-500 \mathrm{~m}$ di atas permukaan laut sambil melakukan perekaman video dan ditransmisikan secara realtime ke Ground Control Station (GCS). Hasil pengujian menunjukkan payload menunjukkan fitur zoomin, zoom-out dan locking target position bisa beroperasi dengan baik. Fitur ini sangat bermanfaat untuk memenuhi kebutuhan operasi illegal fishing pada sistem survey maritime.
\end{abstract}

Kata kunci - payload video, UAV, video recording

\begin{abstract}
The Aeronautics Technology Center of LAPAN develops a maritime surveillance system (MSS) based on an unmanned aerial vehicle (UAV) application, specifically to support the handling of illegal fishing vessels. This article discusses video payload testing. The test was carried out in the coastal area, Pamengpeuk, Garut, Indonesia on August 31, 2019. This place was chosen to simulate conditions with wind speeds that are similar to operating conditions in the marine environment during the actual implementation of the operation. The payload used has a video recording feature with the ability to zoom-in, zoom-out and locking-targetpositions. UAVs fly loiter at an altitude of $300 \mathrm{~m}-500 \mathrm{~m}$ above sea level while doing video recording and transmitted in real time to the Ground Control Station (GCS). The test results show the payload shows the zoom-in, zoom-out and locking target position features can operate properly. This feature is very useful to meet the needs of illegal fishing operations in the maritime survey system.
\end{abstract}

Keywords — video payload, UAV, video recording

Received December $1^{\text {st }}, 2019 ;$ Revised April 28 ${ }^{\text {th }}, 2020 ;$ Accepted April $30^{\text {th }}, 2020$ 


\section{PENDAHULUAN}

Pusat Teknologi Penerbangan LAPAN mengembangkan sistem maritime surveillance system (MSS) berbasis aplikasi unmanned aerial vehicle (UAV), khususnya untuk mendukung penanganan kapal illegal fishing. Kemajuan UAV saat ini implementasinya telah mencakup di berbagai bidang. Dalam tulisan ini dibahas penggunaan UAV untuk mendukung penanganan kapal illegal fishing di Indonesia. Untuk menjalankan misi tersebut UAV harus didukung oleh payload yang memiliki fitur deteksi obyek dan object tracking (pelacakan object).

Beberapa penelitian pengembangan algoritma tracking telah banyak dikembangkan, seperti metode visual tracking system (Ashraf Qadir, et al, 2018)[1], melakukan tuning parameter tipe algoritma control berbasis analisa perpindahan kinematic (Pablo Garcia-Aunon, et al, 2017)[2], membuat aliran optic buatan dengan memperkirakan gerakan kamera antara dua frame video berikutnya (Gonzalo R. Rodr'1guez-Canosa, et al, 2012)[3], metode mean shift object tracking algorithm (Pengfei Fang, et al, 2011)[4], deteksi serta tracking multi wahana bergerak (Min-Hyuck Lee dan Seokwon Yeom, 2018) [5], tracking berbasis pengamatan dan deteksi rintangan untuk navigasi UAV (Yuanwei Wu, Yao Sui, Guanghui Wang, 2017) [6], pengenalan obyek bergerak menggunakan teknik latar belakang [7],[8]. Sedangkan untuk implementasi dari kemampuan deteksi obyek ini dapat diterapkan pada aplikasi untuk SAR (Search and Rescue) (Jingxuan Sun, et al, 2016)[9][10]. Pada penelitian-penelitian terbaru telah dilakukan pendekatan deteksi dan pelacakan otomatis terhadap kapal yang bergerak dengan menggunakan video satelit (Haichao Li, et al, 2019)[13], metode deteksi dan pelacakan kapal menggunakan aliran video dari sistem pemantauan yang ada (CCTV) untuk pelabuhan dan sungai (Natalia Wawrzyniak, et al, 2019)[14], deteksi dan pengenalan objek bergerak dalam urutan gambar yang diambil dari UAV menggunakan teknik baru dan efisien untuk mencapai hasil secara in real time dan in real inveronment (Whyu Rahmaniar, et al, 2019)[15].

Dalam Pelacakan Objek Video (video object tracking), tujuannya adalah untuk menemukan satu atau beberapa objek menarik ("target") di setiap bingkai video. Biasanya pelacakan menemukan target dengan menggambar persegi panjang sekecil mungkin ("kotak pembatas") di mana ia yang masih memungkinkan diproses. Aplikasi Pelacakan Objek Video sangat luas, misalnya, dapat digunakan dalam mengemudi secara otonom, pengawasan, interaksi manusia-komputer, dan sebagainya. Ada dua pendekatan utama metode pelacakan yaitu, Pelacakan Obyek Tunggal (SOT- Single Object Tracking) dan Pelacakan Banyak Obyek (MOTMultiple Object Trancking). Dalam Single Object Tracking (SOT), kotak pembatas dari target dalam bingkai pertama diberikan kepada tracker. Tujuan tracker adalah untuk menemukan target yang sama di semua bingkai lainnya. SOT termasuk dalam kategori tracking deteksi bebas (detection-free tracking), karena secara manual memberikan kotak pembatas pertama kepada tracker. Ini berarti bahwa SOT harus dapat melacak objek apa pun yang diberikan, bahkan objek yang tidak dilatih dengan model klasifikasi yang tersedia. SOT sering disebut juga sebagai VOTVisual Object Tracking (Pelacakan Objek Visual). Sedangkan pada MOT ada beberapa objek yang dilacak (to track). Algoritma tracking pada MOT, pertama menentukan jumlah objek di setiap frame, dan kedua melacak identitas masing-masing objek dari satu frame ke frame berikutnya. Pada makalah ini dibahas metode SOT dengan menggunakan payload video yang dilengkapi dengan kemampuan fitur zoom-in, zoom-out, dan lock object position pada pesawat UAV untuk memberikan solusi verifikasi deteksi kapal illegal yang sering terjadi di Indonesia. Jadi penekanan pada makalah ini adalah pengujian performa fitur zoom-in, zoom-out, lock object position target pada payload video yang bisa memberikan solusi sebagai pendeteksi object kapal illegal pada penerapan berikutnya.

Tujuan dari riset ini adalah mengimplementasikan payload camera video UAV yang dapat diterapkan untuk mengumpulkan data citra (image atau video) sebagai data validasi terhadap identitas kapal yang diindikasikan illegal. Pada tulisan ini dibahas pengujian implementasi payload video di daerah pantai laut Pamengpeuk untuk persiapan implementasi

IJEIS Vol. 10, No. 1, April 2020 : $21-30$ 
secara riil berikutnya untuk pemantauan aktivitas kapal illegal fishing. Tempat ini dipilih untuk mensimulasikan kondisi dengan kecepatan angin yang mirip sama dengan kondisi operasi di lingkungan laut saat implementasi riil operasi. Konsep operasi ditunjukkan pada Gambar 1.

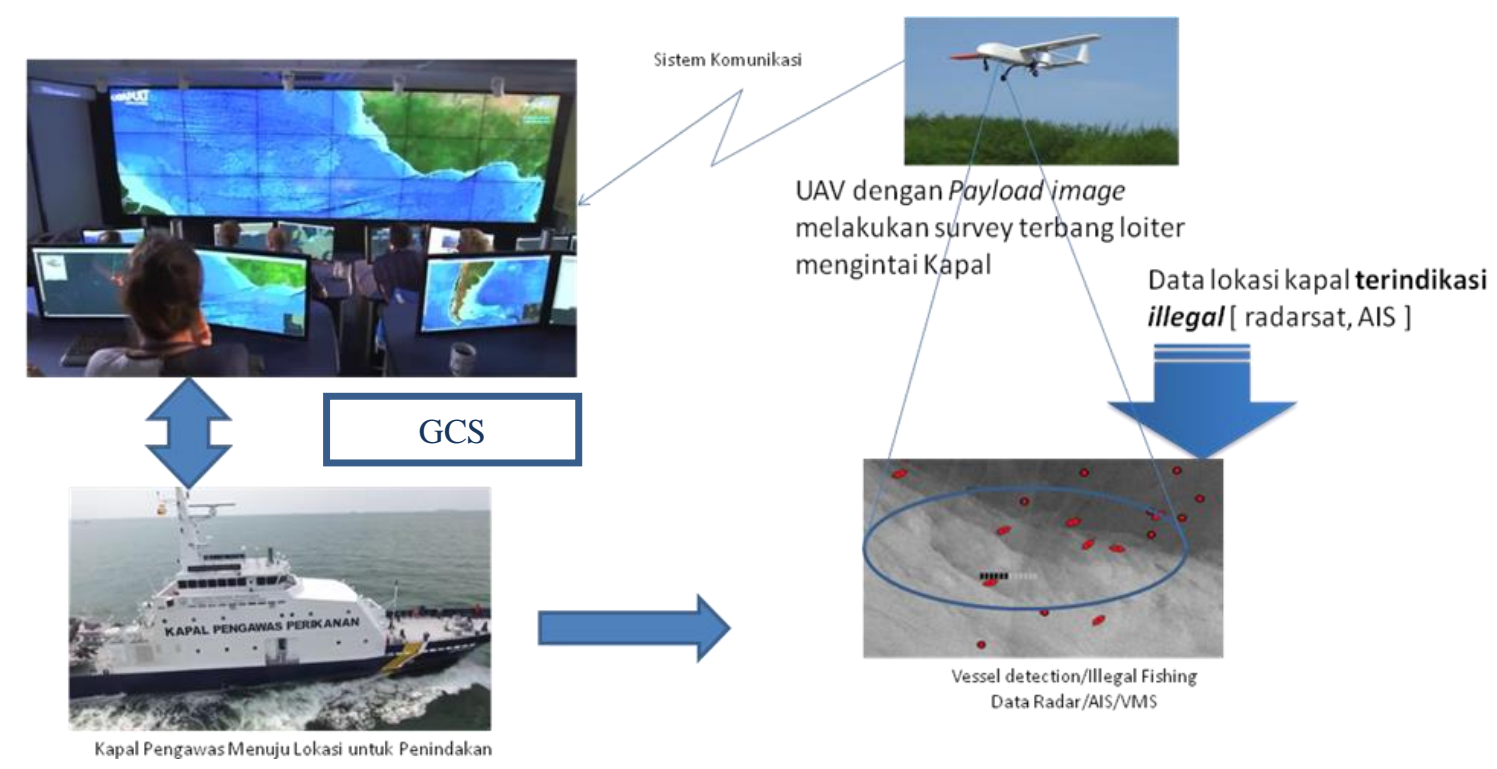

Gambar 1 Konsep operasi pemantauan illegal fishing menggunakan UAV[6].

Setelah data radar dianalisa dan menyatakan terdapat kapal yang teridentifikasi sebagai kapal penangkap ikan secara illegal, maka UAV terbang dengan ketinggian 300 - 500 m dikirim ke lokasi kapal tersebut. Muatan kamera video UAV memotret/merekam kapal tersebut kemudian dikirim ke Ground Control Station (GCS), setelah awak GCS menganalisa bahwa benar data kapal yang dikirim oleh UAV adalah illegal, maka kapal pengawas bergerak menuju ke lokasi untuk melakukan penindakan.

\section{METODE PENELITIAN}

Metode penelitian meliputi analisa permasalahan yang timbul yaitu masalah operasi illegal fishing oleh Kementerian Kelautan dan Perikanan (KKP) saat ini membutuhkan pesawat UAV yang dilengkapi payload camera/video untuk memverifikasi kapal-kapal yang terdeteksi oleh data satelit terindikasi illegal agar lebih efisien dalam biaya operasi. Untuk menjawab permasalahan tersebut maka diperlukan langkah-langkah dalam penelitian yaitu : Pengumpulan data atau informasi tentang kelautan, karakteristik payload kamera, studi literatur mengenai aplikasi payload image/video untuk ship detection, data akuisisi image kamera dikirimkan ke GCS(Ground Control Station), dilanjutkan rancang bangun sistem payload kamera/video yang dilengkapi sistem gimbal sampai ke tahap pengujian di lapangan. Hasil pengujian payload dianalisa, dievaluasi dan dioptimasi untuk perbaikan berikutnya.

Pengujian dilakukan di Pamengpeuk, Garut, Jawa Barat tanggal 31 Agustus 2019. Payload kamera yang digunakan ditunjukkan pada gambar 2 memiliki spesifikasi pada tabel 1. Lingkungan pengujian dilakukan di pantai dengan kecepatan angin rata-rata $10-20$ knot (sekitar $5-10 \mathrm{~m} / \mathrm{s}$ ). Pengujian dilakukan di daerah pantai yang memiliki kecepatan angin tinggi dimaksudkan untuk simulasi kondisi lingkungan yang mempengaruhi performa payload jika disbanding dengan pengujian pada area dengan kecepatan angin yang relative rendah (area non pantai), dengan demikian hasil pengujian bisa digunakan sebagai rekomendasi untuk 
implementasi berikutnya pada lingkungan laut dimana akan digunakan sebagai verifikasi kapal illegal di lautan lepas.

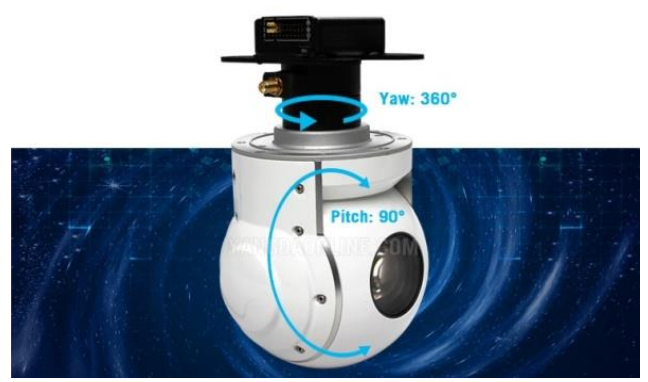

Gambar 2 payload video UAV

Tabel 1. Spesifikasi payload video

\begin{tabular}{|c|c|c|c|}
\hline Sensor & 1/2.8-type Exmor CMOS & \multicolumn{2}{|c|}{ Gimbal system } \\
\hline Video Output & $\begin{array}{l}\text { 1080P/60 HD-SDI and } \\
\text { Ethernet }\end{array}$ & Input voltage & $3 S-4 S$ \\
\hline $\begin{array}{l}\text { Video } \\
\text { recorded }\end{array}$ & $1080 P / 30$ H.264 & Rotate range & Pitch: $\pm 90^{\circ}$ Yaw: Unlimited \\
\hline Focal length & $\begin{array}{l}30 X \text { optical focal zoom, } 4.3- \\
129 \mathrm{~mm}\end{array}$ & $\begin{array}{l}\text { Angle amount of } \\
\text { jitter }\end{array}$ & Pitch: $\pm 0.02^{\circ}$ Yaw: $\pm 0.03^{\circ}$ \\
\hline Digital zoom & $\begin{array}{l}12 X(360 X \text { with optical } \\
\text { zoom })\end{array}$ & Control interface & $P W M$ and serial command \\
\hline $\begin{array}{l}\text { Wide } \\
\text { Dynamic }\end{array}$ & Up to $105 \mathrm{~dB}$ & Working Current & $\begin{array}{l}\text { Static current: } \\
330 m A(@ 12 \mathrm{~V}) \\
\text { Dynamic current: } \\
450 \mathrm{~mA}(@ 12 \mathrm{~V})\end{array}$ \\
\hline Auto focus & Less than $1 S$ & & \\
\hline $\begin{array}{l}\text { Low } \\
\text { illumination }\end{array}$ & $\begin{array}{l}\text { Color: } 0.01 \text { lx }(F 1.6, A G C \\
\text { on,1/30s) }\end{array}$ & & \\
\hline Aperture & $\Phi 16.0$ & & \\
\hline
\end{tabular}

Sebelum dimulai pengujian dilakukan setting misi terbang di Ground Control Sistem (GCS) terlebih dahulu, setting misi tersebut berupa jalur dan ketinggian terbang, dapat dilihat pada Gambar 3. Misi terbang ditetapkan berupa 14 titik (point) yang membentuk jalur terbang disebut sebagai waypoints dengan ketinggian yang bervariasi dengan range dari $300-500 \mathrm{~m}$. 


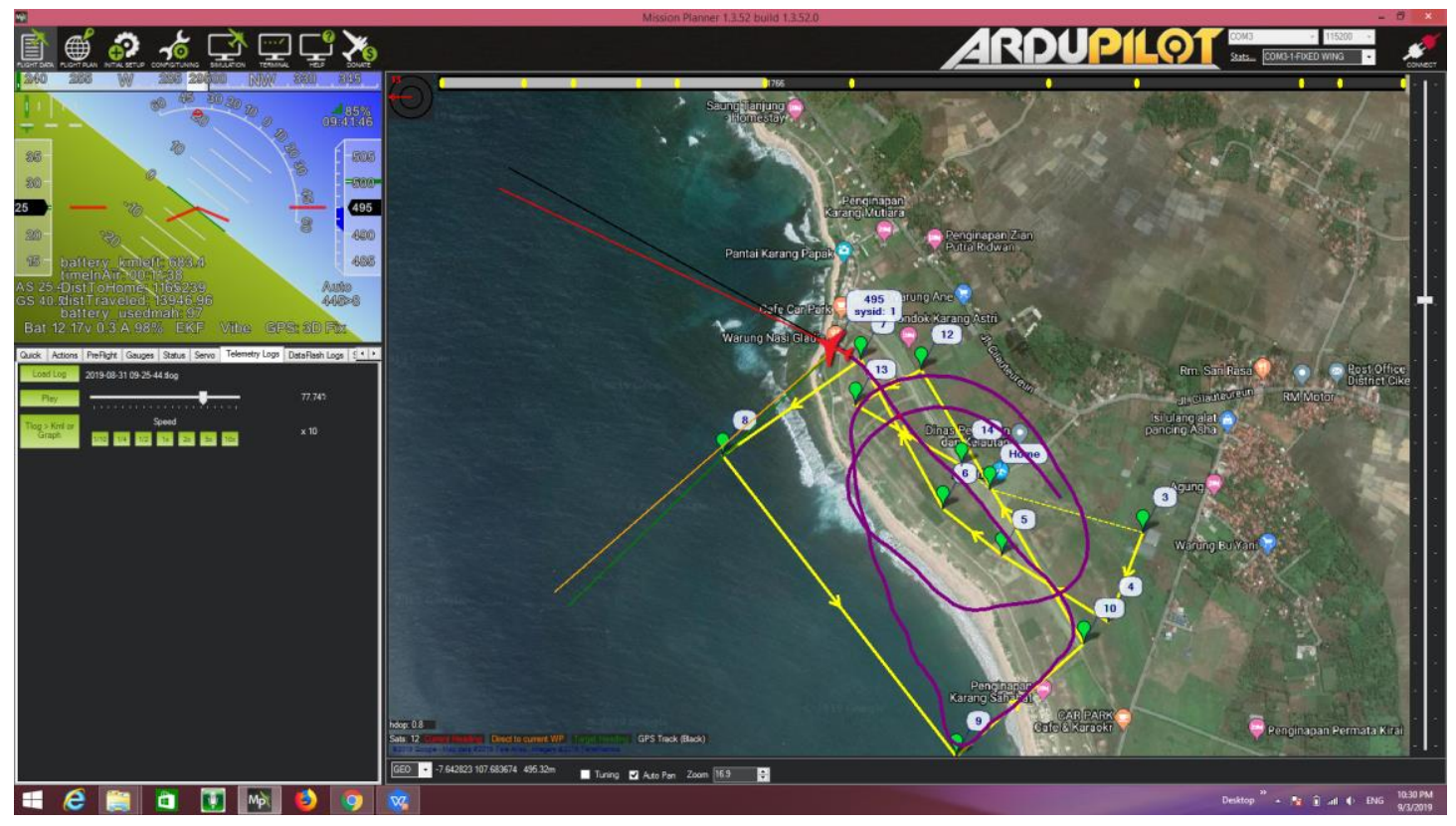

Gambar 3 lokasi dan rute waypoints pengujian menggunakan software Ardupilot[7]

\section{HASIL DAN PEMBAHASAN}

Tujuan pengujian ini adalah untuk mengetahui performa payload video dengan menguji fitur zoom-in, zoom-out, dan locking position target yang sangat dibutuhkan pada implementasi deteksi kapal illegal fishing pada riil implementasi berikutnya.

Pengujian dilakukan selama 14 menit (pukul 09.31 - 09.45 WIB) dengan mode autopilot mengikuti waypoints yang sudah disetting sebelumnya, sebagai sampling untuk mengetahui performa kinerja payload selama kondisi terbang. Data-data hasil pengujian diperlihatkan pada gambar-gambar di bawah. Gambar 4 menunjukkan kecepatan angin fluktuatif yang dapat dijelaskan berikut; kecepatan rata-rata $5 \mathrm{~m} / \mathrm{s}$ pada menit pertama sampai dengan menit ke-3, kecepatan rata-rata $8 \mathrm{~m} / \mathrm{s}$ di menit ke-5 sampai dengan menit ke-9 dan kecepatan tertinggi di $11 \mathrm{~m} / \mathrm{s}$ di menit ke-4 dan ke-12. Titik offset grafik pada angka 25 . Demikian juga data-data ground speed (GS) diperlihatkan pada gambar 5.

Grafik 6 dan 7 menunjukkan perilaku platform pesawat (UAV) saat terbang, gambar 6 menunjukkan perubahan sudut Roll/kemiringan (dalam derajat) sedangkan gambar 7 menunjukkan perubahan sudut pitch / anggukan pesawat (dalam derajat). Pada gambar 6 terjadi roll ekstrim di menit ke-4 (09.35) yaitu -100 derajat miring ke kiri dan di menit ke- 11.5 $(09.42,5$ ) sekitar 99 derajat miring ke kanan. Bersamaan dengan roll yang ekstrim di menit ke-4 juga terjadi pitch ekstrim yaitu -50 derajat ke bawah (nose down). 


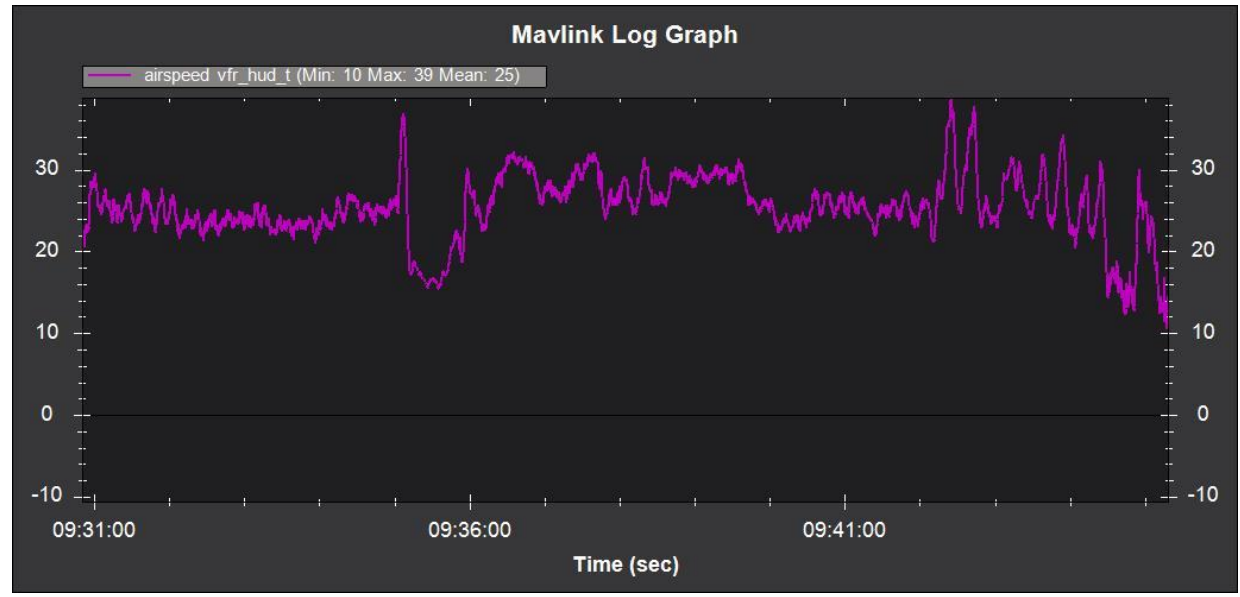

Gambar 4 Grafik kecepatan angin (airspeed) uji terbang Payload Monitoring

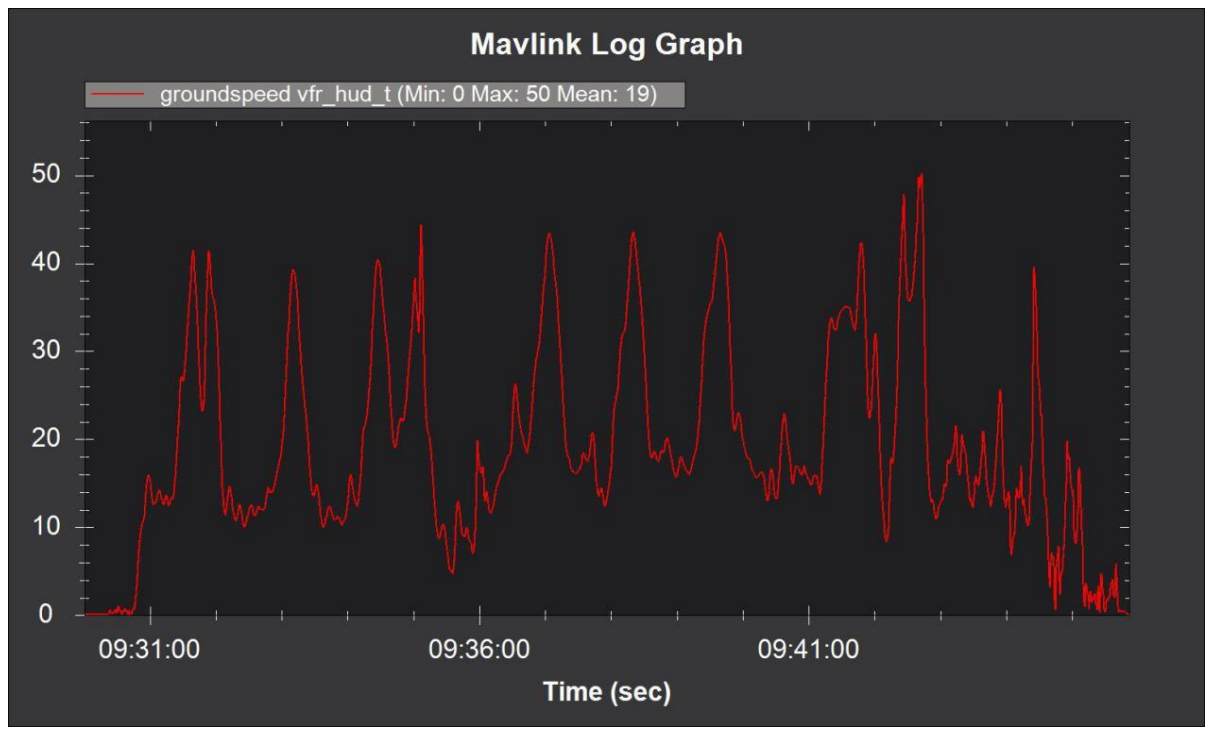

Gambar 5 Grafik Groundspeed Uji terbang Payload Monitoring

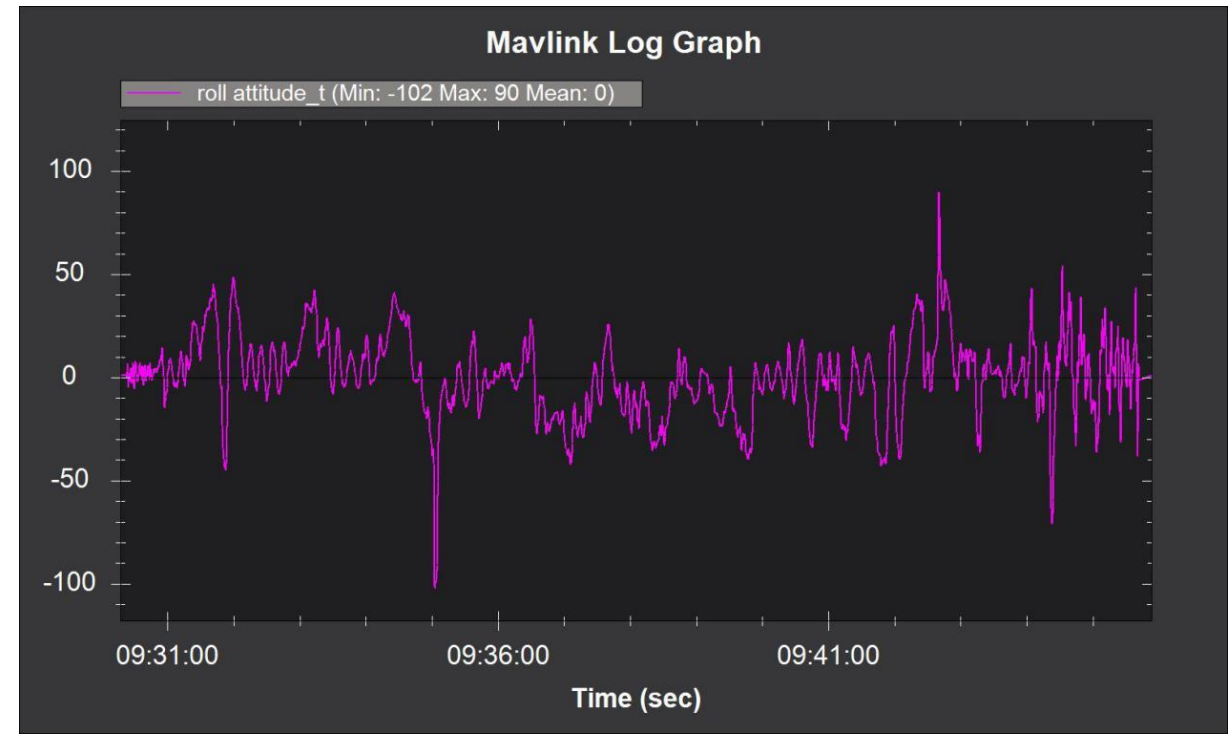

Gambar 6 Grafik Roll Uji terbang Payload Monitoring

IJEIS Vol. 10, No. 1, April 2020 : $21-30$ 


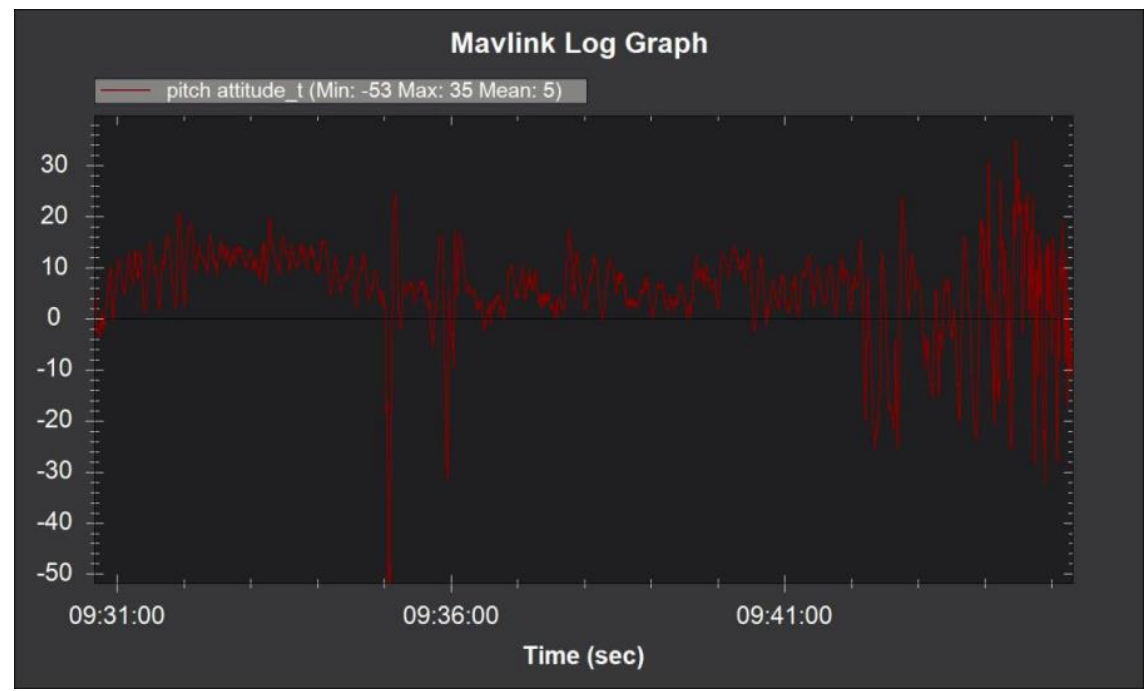

Gambar 7 Grafik Pitch Uji terbang Payload Monitoring

Meskipun dengan kondisi kecepatan angin yang tinggi yang menyebabkan kondisi attitude UAV yang tidak begitu tenang, hasil payload video masih cukup clear dan cukup memenuhi persyaratan untuk operasi deteksi kapal illegal fishing ke depannya. Hasil image video saat terbang loiter dapat dilihat pada gambar 8-10 di bawah, yaitu saat melakukan fitur mode zoom-in, zoom-out, dan lock target posisi. Kamera payload tetap mengarah kepada posisi yang telah di-lock meskipun pesawat UAV sedang bergerak. Ketiga fitur ini sangat bermanfaat saat operasi monitoring kapal yang dicurigai sebagai illegal fishing. Hal ini menunjukkan kecepatan angin tinggi yang menyebabkan perilaku pesawat kurang stabil tidak mempengaruhi kualitas video dari payload yang digunakan.

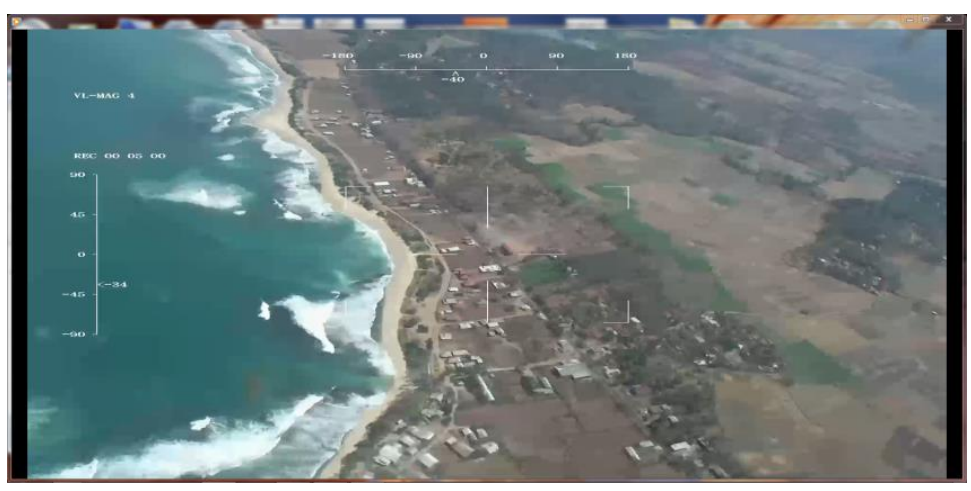

Gambar 8 Image video saat mode zoom-out uji terbang payload monitoring

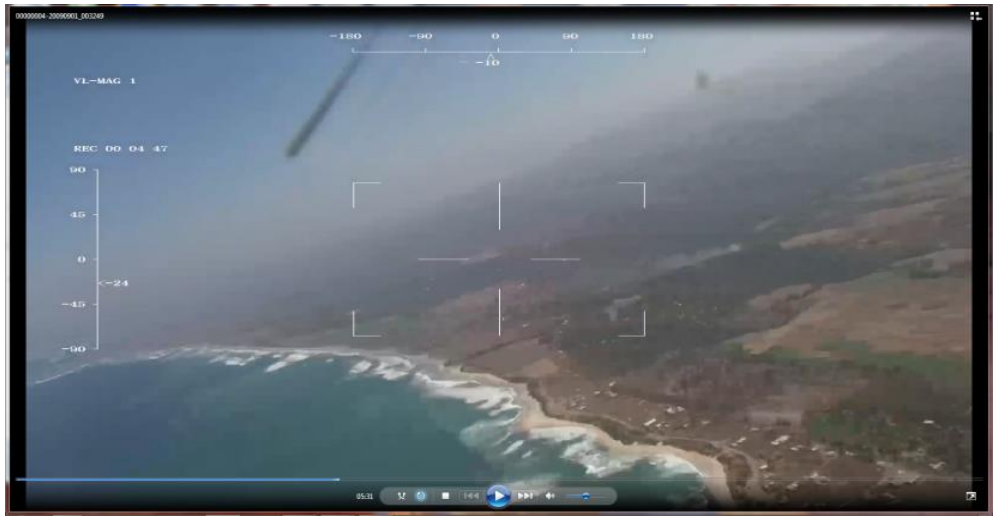

Gambar 9 Image video saat mode zoom-in uji terbang payload monitoring 


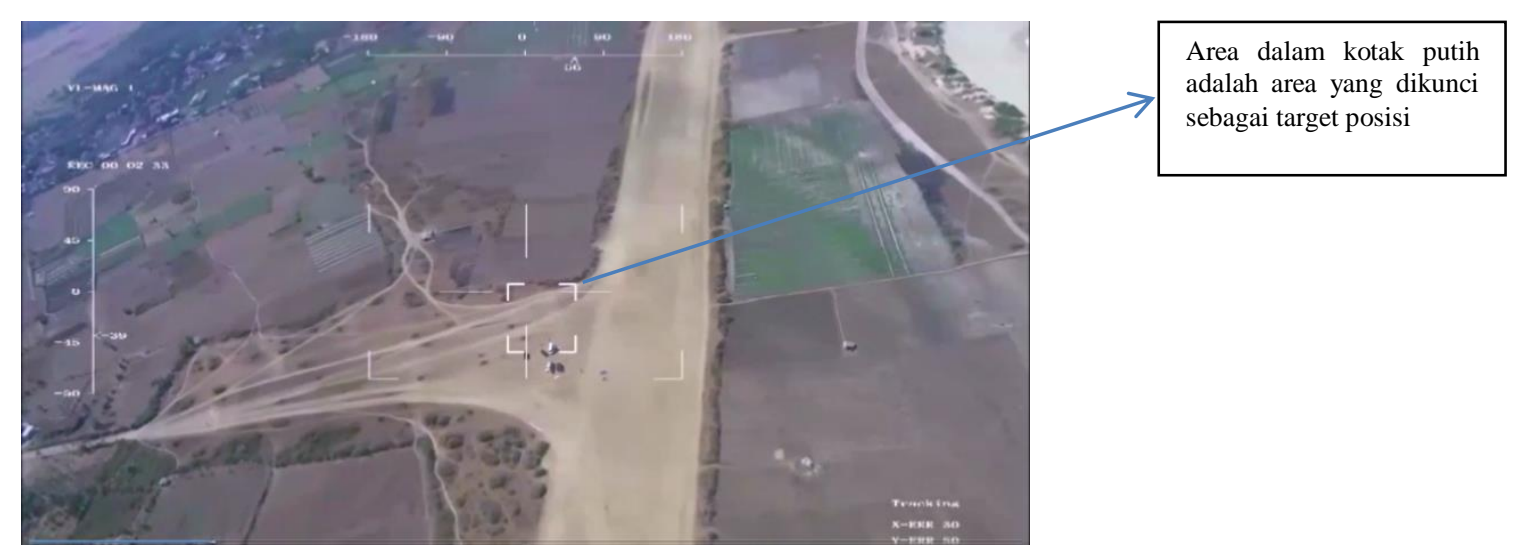

Gambar 10 Image video saat mode lock target posisi uji terbang payload monitoring

\section{KESIMPULAN DAN SARAN}

Telah dilakukan pengujian payload video UAV yang memiliki fitur video recording dengan kemampuan zoom-in, zoom-out dan lock target position dengan operasi ketinggian 300 - $500 \mathrm{~m}$ di atas permukaan laut. Dari pengujian diketahui kondisi kecepatan angin tertinggi di lingkungan pantai Pamengpeuk, Garut sampai dengan $11 \mathrm{~m} / \mathrm{s}$ (sekitar 21 knot) dimana kondisi ini telah mewakili kondisi riil jika berikutnya dioperasikan di tengah laut dengan take-off dari Kapal Laut. Meski sempat mengalami attitude roll dan pitch secara ekstrim -100 derajat miring ke kiri dan -50 derajat nose down, payload masih bisa bekerja dengan baik menjalankan fitur zoom-in, zoom-out dan lock target positionnya. Dengan demikian sistem payload ini dapat direkomendasikan untuk diuji terbang berikutnya dengan misi riil di laut dengan take-off dari kapal laut untuk misi verifikasi kapal-kapal yang terindikasi sebagai illegal fishing.

\section{UCAPAN TERIMA KASIH}

Penulis mengucapkan terima kasih kepada PT. Aeroterra Indonesia yang telah berkolaborasi dalam pengujian dan kepada penyandang dana dari Program Insentif Riset Sistem Inovasi Nasional (INSINAS) 2019, Direktorat Jenderal Penguatan Riset dan Pengembangan, Kementerian Riset, Teknologi, dan Pendidikan Tinggi.

\section{DAFTAR PUSTAKA}

[1] Ashraf Qadir, Jeremiah Neubert and William Semke, "On-Board Visual Tracking with Unmanned Aircraft System (UAS)," Unmanned Aircraft Systems Engineering (UASE) Laboratory at the University of North Dakota, American Institute of Aeronautics and Astronautics.

IJEIS Vol. 10, No. 1, April 2020 : $21-30$ 
[2] Pablo Garcia-Aunon, Matilde Santos Penas and Jesus Manuel de la Cruz Garcia, "A new UAV ship-tracking algorithm," IFAC (International Federation of Automatic Control) Hosting by Elsevier Ltd, 2017

[3] Gonzalo R. Rodriguez-Canosa, Stephen Thomas, Jaime del Cerro, Antonio Barrientos and Bruce MacDonald, "A real-Time Method to Detect and Track Moving Objects (DATMO) from Unmanned Aerial Vehicles (UAVs) Using a Single Camera," J.Remote Sensing.2012, 4, 1090-1111; doi:10.3390/rs4041090

[4] Pengfei Fang, Jiangjiang Lu, Yulong Tian and Zhuang Miao, "An improved tracking method in UAV videos," Procedia Engineering, 2011, SciVerse ScienceDirect, Availabel online at www.sciencedirect.com

[5] Min-Hyuck Lee and Seokwon Yeom, "Detection and Tracking of Multiple Moving Vehicles with a UAV," International Journal of Fuzzy Logic and Intelligent System, 2018, http://doi.org/10.5391/IJFIS.2018.18.3.182

[6] Yuanwei Wu, Yao Sui and Guanghui Wang, "Vision-based Real-Time Aerial Object Localization and Tracking for UAV Sensing System," Computer Vision and Pattern Recognition, 2017, Available : https://arxiv.org/abs/1703.06527

[7] Mervin K. and Sarala B.,'Moving Object Recognition Using Background Substraction and Image Processing Techniques," International Journal of Scientific Engineering and Applied Science (IJSEAS), 2015

[8] Shen Hao, Li Shuxiao, Zhu Chengfei, Chang Hongxing and Zhang Jinglan, " Moving object detection in aerial video based on spatiotemporal salienc," Chinese Journal of Aeronautics, 2013, http://dx.doi.org/10.1016/j.cja.2013.07.038

[9] Jingxuan Sun, Boyang Li, Yifan Jiang and Chih-yung Wen, "A Camera-Based Target Detection and Positioning UAV System for Search and Rescue (SAR) Purposes," $J$. Sensors, 2016, 16, 1778; doi:10.3390/s16111778. Available : https://www.mdpi.com/journal/sensors

[10] Michael A. Goodrich, Bryan S. Morse, Damon Gerhardt, Joseph L. Cooper, Morgan Quigley, Julie A. Adams and Curtis Humphrey, "Supporting wilderness search and rescue using a camera-equipped mini uav," J. Field Robot, 2008, 25, 89-110; doi:10.1002/rob.20226.

[11] Sunar, "Pengembangan Sistem Payload UAV untuk Pemantauan Maritim," Laporan Akhir Tahun Program Insinas Riset Pratama Individu Ristekdikti, 2018

[12] _. "Mission Planner Home," http://ardupilot.org/planner/, (C) Copyright 2019, ArduPilot Dev Team.

[13] Haichao Li, Liang Chen, Feng Li, Meiyu Huang, "Ship detection and tracking method for satellite video based on multiscale saliency and surrounding contrast analysis", $J$. Appl. Reemote Sens. 13(2), 026511 (2019), doi: 10.1117/1.JRS.13.026511 
[14] Natalia Wawrzyniak, Tomasz Hyla, and Adrian Popik, "Vessel Detection and Tracking Method Based on Video Surveillance", J. Sensors (2019), 19, doi:10.3390/s19235230, www.mdpi.com/journal/sensors

[15] Wahyu Rahmaniar, Wen-June Wang and Hsiang-Chieh Chen, "Real-Time Detection and Recognition of Multiple Moving Objects for Aerial Surveillance", J. Electronics 2019, 8, 1373; doi:10.3390/electronics8121373, www.mdpi.com/journal/electronics 